Article

\title{
Ensuring More Sustainable Reporting in Europe Using Non-Financial Disclosure-De Facto and De Jure Evidence
}

\author{
Francesca Manes-Rossi ${ }^{1, *}$ (D), Adriana Tiron-Tudor ${ }^{2}$ (I) , Giuseppe Nicolò ${ }^{1 \text { (I) }}$ \\ and Gianluca Zanellato ${ }^{2}$ \\ 1 Department of Management and Innovation Systems, University of Salerno, Via Giovanni Paolo II, 132, \\ 84084 Fisciano (SA), Italy; gnicolo@unisa.it \\ 2 Faculty of Economics and Business Administration, Babes-Bolyai University, Strada Teodor Mihali, Nr. 58-60, \\ Campus FSEGA, 400591 Cluj-Napoca, Romania; adriana.tiron@econ.ubbcluj.ro (A.T.-T); \\ gianluca.zanellato@econ.ubbcluj.ro (G.Z.) \\ * Correspondence: fmanesrossi@unisa.it; Tel.: +39-089-96-31-31
}

Received: 18 March 2018; Accepted: 10 April 2018; Published: 13 April 2018

\begin{abstract}
Non-financial disclosure has become increasingly popular, as it can satisfy the information needs of a growing range of stakeholders. Because traditional financial reports cannot provide comprehensive accountability, several frameworks and guidelines for facilitating non-financial information disclosure have been developed. Recently, the European Union issued Directive 2014/95/EU (EU Directive) and subsequent guidelines (EU Guidelines 2017/C215/01 [EUG]) to mandate European entities of public interest to convey non-financial information to improve such organizations' accountability toward their stakeholders. This paper studies the European stage of non-financial reporting from a regulatory and practical point of view. To this end, the first research objective is to analyze the elements that the EUG have in common with the IIRF and the GRI 4 guidelines. Second, the paper proposes a first analysis to assess the compliance to the EUG by performing a content analysis on a sample of annual reports and integrated reports (IR) drafted by the 50 biggest European companies. The results highlight that the content elements required by the Directive exceed the requirements of the two frameworks and that there is already a high level of compliance by European big companies with the EUG. More specifically, particular attention is devoted to Social, Employee and Environmental Matters. Accordingly, the companies demonstrated a common awareness of the necessity to provide an exhaustive amount of social and environmental disclosure in order to maintain legitimacy. Also the disclosure on Principal Risks and Their Management is widespread to meet investors' and stakeholders' requirements in recent years with respect to the general level of risk disclosure provided by companies.
\end{abstract}

Keywords: integrated reporting; sustainability reporting; European Directive 2014/95/EU; European companies; content analysis

\section{Introduction}

The financial crises and growing concerns regarding the social and environmental consequences of companies' activities have dramatically increased the external pressure on companies to be more accountable toward and more transparent with their investors and stakeholders [1-6].

In this context, current accounting systems, which are mainly based on retrospective financial data, have been considered inadequate for satisfying the information needs of investors and other stakeholders and thus for providing an acceptable level of transparency and accountability [3,7-9]. 
Indeed, investors and stakeholders increasingly require more non-financial information about companies' risk, governance and social and environmental issues in a more connected and comprehensive manner [10-12].

In particular, after the Earth Summit in 1992 and the advent of the Kyoto protocol in 1997, which shed light on climate changes and other associated environmental risks, the theme of sustainability and sustainable development have acquired pivotal importance as the "development that meets the needs of the present without compromising the ability of future generations to meet their own needs" [13] (p. 234).

The relevance of Corporate Social Responsibility (CSR) emerged consistently, representing its logical extension to business' responsibility to contribute in a positive way to society's well-being, beyond a narrow focus on profit maximization $[2,14,15]$.

According to Guthrie and Parker [16] (p. 67), CSR disclosure is deemed as essential in reducing information asymmetries between stakeholders and management and reducing the market risk of capital investments.

In line with CSR discourse, non-financial disclosure has acquired a fundamental role in expanding the magnitude of companies beyond the financial account for shareholders, embracing a broader perspective including the different dimensions linked to the social, environmental, ethical, risk and governance aspect that are of interest of all stakeholders [16-18].

As Solomon and Maroun state [19] (p. 6), "companies are expected to achieve integration of sustainability and governance information within the annual report. Such integration is deemed essential if businesses are to embed stakeholder accountability into the heart of their operations in a meaningful way."

Nevertheless, sustainability reports, although based on the Global Reporting Initiative (GRI) guidelines, tend to disclose social, environmental and governance information separately from financial information, without providing an integrated and comprehensive picture of these issues and of their interconnections $[5,13,19]$. For this reason, "non-financial information fails to provide stakeholders with necessary links and connections to effectively evaluate business performance strategy and future value creation", according to Wild and van Staden [7] (p. 6).

To address the missing linkages and lack of connectivity of previous reports, a new trend in corporate reporting emerged to convey financial and non-financial information in one document known as an Integrated Report (IR) [19-21]. The International Integrated Reporting Council (IIRC) issued in 2013 a specific framework (International Integrated Reporting Framework [IIRF]) to support entities in the preparation of the document. An Integrated Report aims to expose "a holistic picture of the combination, interrelatedness and dependencies between the factors that affect the organization's ability to create value over time" [22]. Although Integrated Reporting caught the interest of many companies, it remains voluntary in all countries besides South-Africa [10].

In recent years, the European Union (EU) has taken a step forward to address investors' and stakeholders' information needs regarding long-term risks as well as environmental and social sustainability. To this end, the EU issues the Directive 2014/95/EU (EU Directive) [23] to require large entities of public interest to disclose financial information, and EU Guidelines 2017/C215/01 (EUG) [24] to support organizations in providing this disclosure. The EU Directive aims to ensure that organizations provide at least a 'package' of information that is considered unavoidable and comprehensive non-financial information. Moreover, the specific purpose of the EUG [24] (p. 4) is to "help companies disclose high quality, relevant, useful, consistent and more comparable non-financial (environmental, social and governance-related) information in a way that fosters resilient and sustainable growth and employment, and provides transparency to stakeholders [ ... ]. They are intended to help companies draw up relevant, useful concise non-financial statements according to the requirements of the Directive."

Grounded on this theoretical and legislative background, the study has two related research aims: first, the study aims to investigate what the EUG, IIRF, and GRI 4 guidelines have in common to determine to what extent these frameworks meet the requirements of the Directive. Second, because 
the EU Directive together with the EUG will become mandatory for certain types of companies, this study aims to evaluate big companies' readiness for change. To this end, we run a first analysis to assess the compliance to the EUG by performing a content analysis on a sample of annual reports and integrated reports (IR) drafted by the 50 biggest European companies selected on the basis of market capitalization. An un-weighted disclosure index is developed to analyze the selected companies' level of compliance with the EUG. All the sampled firms can be considered entities of public interest according to EU directives, including listed companies, banks and assurance companies with more than 500 employees, and are selected because they are considered as recipients of the EU Directive.

The results of the research may be useful for detecting organizations' state of readiness for change regarding non-financial information disclosure and for identifying whether the biggest European companies, which fit the definition of entities of public interest provided by the EU directive, are already compliant with the EUG. Moreover, this study may contribute to research regarding non-financial information practices and offer useful recommendations for standard setters and policy-makers to improve the quality of non-financial information.

The paper proceeds as follows: Section 2 provides a detailed literature review on non-financial information that focuses on previous compliance research regarding the IIRF, GRI 4 guidelines and EUG. Section 3 presents the theoretical framework of the study and illustrates the research methodology, while Section 4 discusses the results of the study. Section 5 discusses the implications of the study and provides suggestions for future research.

\section{Literature Review and Theoretical Background}

CSR and sustainability themes have progressively gained momentum as strategic factors for firm's survival and success $[2,4,6,12,14,25]$.

Accordingly, a firm's survival can no longer be traced back only to an economic dimension of profit maximization, but it has to be included in a broader discourse encompassing the way in which the firm manages the risks arising from the social and environmental impacts of its activities in the medium and long term and demonstrates to be socially responsible $[14,26]$.

As a result, researchers, practitioners and standard setters have become increasingly interested in the inclusion of non-financial information in annual reports. Non-financial information refers to a broad range of themes and issues such as environmental and social policies and impacts (e.g., resource and energy use, greenhouse gas emissions, pollution, biodiversity, climate change, waste treatment, health and safety of employees, gender equality, education) and is pivotal to improve accountability and transparency towards stakeholders [2,14-18,27].This emerging trend of reporting non-financial information has led to wider adoption of sustainability reports to provide stakeholders with "financial and non-financial information relating to an organization's interaction with its physical and social environment, as stated in corporate annual reports or separate social reports" [26] (p. 78). According to Nolan [28] (p. 7), this extended reporting model "aims to highlight the view that a company's consideration of only financial matters as an indicator of its success is inadequate."

Sustainability reports allow companies to demonstrate that they are socially responsible and are a powerful tool for improving communication with stakeholder groups by enhancing the transparency and accountability of non-financial information [29].

Empirical studies on sustainability originate in the 70s with the seminal survey conducted by Ernst and Ernst in 1977 on a sample of 500 USA companies and are based on understanding accounting as a social phenomenon [16] (p. 343). These studies continued in the 80s and 90s in the UK [17,30], Australia [16,31,32], and New Zealand [26].

These studies, which were primarily conducted on annual reports, have revealed similar results $[30,33,34]$. First, the non-financial information provision was mainly an isolated phenomenon and not a systematic activity, with a higher prevalence in the USA, the UK, New Zealand, and Australia [26,30]. Most of the non-financial information that was disseminated concerned human resources and community involvement issues with minor references to environmental issues. Only in 
certain critical industry sectors belonging to primary and secondary industries, such as mining, oil and steel companies, environmental disclosure obtain greater diffusion [26]. Other common patterns include the prevalence of a qualitative rather than a quantitative disclosure, the tendency to emphasize only the good news by disclosing the information in a "self-laudatory" way and the positive association between the extent of non-financial disclosure and the firm's size [31].

These studies were mainly framed under the theoretical lens of the legitimacy theory. In this context, the disclosure on sustainability issues represents a response to social and political pressures deriving from the external environment. Disclosure is considered as a suitable instrument to disseminate a good public image and demonstrate that the company is operating within the boundaries and norms established by the society in which it is rooted [16,32,34-37]. The legitimacy is "a status, which exists when an entities value system is congruent with the value system of the larger social system of which the entity is a part. When a disparity, actual or potential, exists between the two value systems, there is a threat to the entities' legitimacy" [35] (p. 2).

Using this theoretical framework, most studies regarding sustainability reporting examine the relationship between particular environmental and social events and incidents or negative media attention and the extent of sustainability disclosure by obtaining results that confirm the usefulness of non-financial disclosure to gain legitimacy $[16,33,36,38]$.

In more recent years, the development and establishment of the GRI guidelines have influenced non-financial disclosure practices to change from a sporadic phenomenon to a systematic activity that involves further strategic aspects, such as firms' risk and opportunities, anti-corruption, corporate governance, and fraud matters management $[14,38,39]$.

As the GRI states, "by using the GRI guidelines, reporting organizations disclose their most critical impacts—-be they positive or negative — on the environment, society and the economy. They can generate reliable, relevant and standardized information with which to assess opportunities and risks, and enable more informed decision-making — both within the business and among its stakeholders" [40] (GRI website). According to the GRI guidelines, firms have started to prepare stand-alone reports, and, in recent years, the number of these individual reports has dramatically grown [3,29,41].

As a response, several studies have aimed to determine whether companies' reports meet the need for accountability by analyzing the level of voluntary disclosure regarding social and environmental issues [29,38,41-43], as well as risks and opportunities [44-46]. More specifically, Cho and Patten [38] investigate a sample of 100 USA listed companies in order to examine the relation between environmental performance and disclosure. Their findings reveal that firms operating in environmentally sensitive industries (e.g., mining, extractive, oil and steel companies) tend to disclose more environmental information than other firms, to obtain legitimacy in their social community. Cho et al. [41] analyzed a sample of 120 sustainability reports issued by firms from six different countries, in order to test the use of graphs to enhance a positive image and to obfuscate negative trends. Their results confirm the hypothesis on the use of stand-alone sustainability reports as "legitimacy tools". In the same vein, Patten and Zhao [29], have conducted an empirical study on a sample of standalone CSR reports within the U.S. retail industry. Sampled companies disclose more environmental than social information, and they tend to focus on discussing programs and initiatives, sometimes neglecting the publication of relevant performance data. Their results provide further empirical evidences on the use of stand-alone CSR reports as an image/reputation enhancement tool rather than as a significant accountability tool [29]. Skouloudis et al. [47] investigate a sample of 16 Greek companies drafting the sustainability reports. They find that reports vary significantly in terms of materiality and completeness of information disclosed and that there is only a partial level of compliance with the GRI guidelines.

Guthrie et al. [42,43] conduct similar studies by focusing the attention on the Australian Food and Beverage Industry (AFBI), in order to examine the level of CSR disclosure provided according to GRI guidelines through different reporting media (annual reports and websites) [43] and the level of CSR disclosure provided according to two different frameworks (GRI and AFBI Industry-specific 
framework) [42]. They find that websites are more suitable than annual reports in disseminating social and environmental information [43] and that GRI guidelines do not capture all the facets of social and environmental issues within specific industry sectors, needing to be enriched and refined [42].

Abraham and Cox [44] narrow the attention on the risk dimension and its determinants, by analyzing the level of risk disclosure provided by a sample of 71 UK listed companies through the annual reports. They find that risk disclosure is focused on financial risk information and that corporate risk reporting is negatively related to share ownership by long-term institutions and positively associated with both the number of executives and the number of independent directors. Also Moolman et al. [45] investigate the risk dimension by analyzing whether integrated reporting has brought changes in the disclosure of risks and opportunities. They find that most of the sampled companies are compliant with all the IIRF requirements for the content element "risks and opportunities" except for the disclosure of the assessment of risks.

Other studies $[3,6]$ also highlighted the choice to voluntarily submit reports to independent assurance to enhance the credibility and perceived quality of the firms' disclosed non-financial information, as doing so consolidates the reputation and legitimacy of the firms within the stakeholders' communities.

In this regard, Guthrie et al. [48] (p. 256) underline that the legitimacy theory presupposes the existence of a sort of "social contract" between the firm and the society in which it is rooted. This ideal social contract regulates the behavior of the company and establishes how it must act in compliance with the society's expectations and values. Thus, an adequate amount of disclosure that evidences how the firm is fully involved in addressing social and environmental issues according to socially acceptable behaviors established by the society is a useful tool for satisfying the society's expectations and information needs $[49,50]$.

However, as already underlined, many scholars $[29,37,38]$ consider that non-financial disclosure conveyed through sustainability reports is mainly oriented to improve the company's image and reputation in a legitimacy perspective rather than to provide a clear and detailed analysis of social and environmental performance as well as the resulting impacts. Consistently, as argued by Patten and Zhao [29] (p. 1), the use of a standalone sustainability report can be criticized because it represents "an exercise designed not for transparent accountability, but instead for nothing more than image enhancement." Moreover, these documents are limited in that they are not mandatory and are not integrated with economic and financial information $[5,13]$.

In this vein, the introduction of the IR framework represents a possible solution, as it requires a more cohesive and integrated approach to corporate reporting through the disclosure of the six capitals (Financial, Manufactured, Intellectual, Human, Social \& Relational and Natural), which should cover all resources involved in firms' value creation and their interconnections $[8,19]$. However, except for in South Africa, IR is not mandatory in any country [5] Some criticism have been raised towards IR since it is focused on the concept of value-to-investors, mainly addressing the information needs of financial capitals providers $[9,10,51,52]$. Moreover, Flower blames the IIRF as it considers mainly the prosperity of the entity, rather than of the society [51] Milne and Gray [53] (p. 20), commenting the IIRF, state: "Despite its claims for sustainable development and sustainability, it is exclusively investor focused and it has virtually nothing — and certainly nothing substantive— to say about either accountability or sustainability".

Another push toward harmonized non-financial disclosure is the European Directive 2014/95/EU. The EU Directive establishes that entities of public interest are required to place non-financial disclosure in a management report or separate statement that focuses on the "development, performance, position and impact of its activity, relating to, as a minimum, environmental, social and employee matters, respect for human rights, anti-corruption and bribery matters." The report should include five pieces of information: "(a) a brief description of the undertaking's business model; (b) a description of the policies pursued by the undertaking in relation to those matters, including due diligence processes implemented; (c) the outcome of those policies; (d) the principal risks related to those matters 
linked to the undertaking's operations including, where relevant and proportionate, its business relationships, products or services which are likely to cause adverse impacts in those areas, and how the undertaking manages those risks; (e) non-financial key performance indicators relevant to the particular business" [23] (pp. 4-5).

The introduction of the EU Directive is pivotal to the improvement of non-financial disclosure. Besides its ability to enhance legitimacy, non-financial disclosure can be beneficial for stakeholders who in recent years, due to crises and scandals, have lost confidence in the market and society [54]. Disclosure regarding risk management and sustainability issues improves firms' evaluation processes and produces positive effects on the market value and equity cost $[44,55,56]$. However, the voluntary nature of this information has mitigated these benefits due to credibility, transparency, and irrelevance drawbacks [57,58].

In this sense, the introduction of mandatory requirements by the Directive 2014/95/EU and the related guidelines issued in 2017 that operationalize how to prepare mandatory information can improve the quality and credibility of non-financial information and increase the comprehensiveness of non-financial information [6].

Some researchers have started to investigate the level of compliance of annual reports with the EUG. More specifically, Guse et al. [59] analyzed the annual reports of 20 Romanian-listed companies for the year 2015 to determine to what extent these companies were prepared to implement the Directive. Their results indicate medium levels of compliance, as most of the content elements were disclosed by about $50 \%$ of the sampled firms. More specifically, regarding the Social and Employee Matters, Guse et al. [59] obtained high compliance levels only for some sub-contents, such as working conditions and respect for the rights of workers, while, they found high values for Environmental Matters, only for some sub-contents related to the impacts on the environment.

In the case of Polish-listed companies, Dyduch and Krasodomska [54] explored 60 annual reports to examine the level of non-financial disclosure provided according to the Directive and factors that may determine the disclosure. They find that more than half of companies do not disclose any environmental information in their annual reports and that some factors such as capital turnover, duration of the stock exchange listing, industry environmental sensitivity, and reputation significantly influence the non-financial disclosure provided in accordance to the EU Directive. Even in the Polish context, Matuszak and Różańska [57] analyze a sample of 150 listed companies focusing on annual reports, CSR reports and companies' websites in order to examine the quality and the extent of CSR disclosure provided as well as the level of compliance with the new requirements of the Polish Accounting Act (PAA) on non-financial disclosure, in accordance with Directive 2014/95/EU. Their study reveals that companies prefer annual reports to communicate voluntary CSR disclosures and that there is a scarce level of compliance with the new PAA requirements on non-financial disclosure. In particular, sampled companies placed little emphasis on reporting about human rights and anti-corruption.

In Italy, Venturelli et al. [58] focused on a sample of 223 large companies considered entities of public interest by analyzing non-financial information disclosed in the mandatory and voluntary reports for the year 2015 and identified a medium level of compliance. In particular, the highest levels of compliance were achieved with regard to two content elements, business model and sustainability policies, while, there was an insufficient level of compliance regarding diversity policies.

Other studies compare the IIRF and the GRI 4 guidelines [60] as well as the IIRF and the EU Directive [61]. Idowu et al. [25] conducted a comparison between the IR framework, ISO 26000 and GRI G4. They found that most of the terms and definitions, elements and principles from ISO 26000 and GRI G4 are found in the IR framework, but in a much broader sense and with the provision of a more in-depth understanding regarding what companies should report and how the disclosed information should be organized in the annual corporate report. Moreover, Paternostro [62] explores the relationship between IR and other reports, such as: Financial Statement, the Management Commentary, Social and Environmental Report, the Corporate Governance Report, and Intellectual Capital Report, proposing three different approaches to prepare IR, favoring the respect of the connectivity principle. 
Nevertheless, there is a lack of research that compares the non-financial disclosure information provided by large companies located in different European regions in terms of the compliance of the companies' reports with the EUG.

Filling the gap, this research contributes to the literature in a twofold manner. First, by comparing the EUG with the IIRF and the GRI guidelines, the study highlights the differences and similarities between the three frameworks. Second, the analysis of the reports published by the 50 largest European Companies for the year 2016 allows for assessing, using legitimacy theory perspective, the level of compliance with EUG and, more broadly, for identifying the readiness for change.

\section{Research Methodology}

The comparison between the EUG, IIRF, and GRI guidelines requires analysis of the three frameworks by referring to the key principles and contents as required by the EUG. From a methodological point of view, according to previous studies $[25,60,61]$, the comparison of the frameworks has been carried out through an in-depth analysis of the frameworks, which were obtained from the frameworks' official websites $[22,24,40]$.

The comparison focuses on the EUG, GRI 4, and IIRF because they can be considered as the most commonly used and influential framework for non-financial information $[5,25,58,61,63]$. We focus on the GRI 4 Guidelines because the research analyzes the reports published in 2016, while the new guidelines issued by the GRI in 2016, the GRI Sustainability Reporting Standards (GRI Standards), will be applicable only by 2018. Furthermore, we conduct an analysis of the reports published by the 50 biggest European public companies per market capitalization, selected by the Forbes 2000 classification.

All the sampled firms can be considered entities of public interest according to article 2 of the EU Directive [64]. The sampled firms include listed companies, banks and assurance companies that have more than 500 employees and were selected because they are considered recipients of the EU Directive. Moreover, the selection of these companies can be explained by the need to analyze to what extent the key contents of the EUG are already included in the companies' reports and thus determine the companies' readiness for change.

The sampled firms were grouped in industry sectors according to Venturelli et al. [58], who classified 223 Italian companies in nine broad categories: Basic Materials, Consumer Goods, Consumer Services, Health care, Industrial, Oil and Gas, Telecommunications, Banks and Financial Services and Insurance. However, because this study is based on a smaller sample, the classification proposed by Venturelli et al. [58] was partially modified by merging the categories of Banks and Financial Services and Insurance into a unique category: Financial Services. Moreover, the category of Basic Materials was removed, as no company belongs to this sector.

Annual reports presented by the companies included in the sample were collected to analyze the compliance of non-financial disclosure to the EUG. However, 10 out of the 50 companies in 2016 published IR as annual reports. Thus, the final sample consists of 40 annual reports and 10 IR.

Table 1 presents the sample and groups the number of companies by country and sector.

Table 1. Study sample in terms of countries and sectors.

\begin{tabular}{ccccccccc}
\hline Country & $\begin{array}{c}\text { Consumer } \\
\text { Goods }\end{array}$ & $\begin{array}{c}\text { Consumer } \\
\text { Services }\end{array}$ & $\begin{array}{c}\text { Financial } \\
\text { Services }\end{array}$ & $\begin{array}{c}\text { Health } \\
\text { Care }\end{array}$ & Industrial & $\begin{array}{c}\text { Oil \& } \\
\text { Gas }\end{array}$ & Telecommunications & Tot. \\
\hline Belgium & 0 & 1 & 0 & 0 & 0 & 0 & 0 & 1 \\
Denmark & 0 & 0 & 0 & 1 & 0 & 0 & 0 & 1 \\
France & 2 & 0 & 2 & 1 & 1 & 1 & 0 & 7 \\
Germany & 4 & 0 & 1 & 1 & 3 & 0 & 2 & 11 \\
Ireland & 0 & 1 & 0 & 2 & 0 & 0 & 1 & 4 \\
Italy & 0 & 1 & 0 & 0 & 0 & 1 & 0 & 4 \\
Netherlands & 1 & 0 & 1 & 0 & 1 & 1 & 0 & 5 \\
Spain & 1 & 1 & 2 & 0 & 0 & 0 & 0 & 1 \\
Sweden & 0 & 0 & 1 & 0 & 0 & 0 & 1 & 14 \\
UK & 4 & 2 & 4 & 1 & 0 & 2 & 5 & 50 \\
\hline Total & 12 & 6 & 11 & 6 & 5 & 5 & & 5 \\
\hline
\end{tabular}


Table 2 groups the companies in the sample by sector and indicates the average number of employees and the average market value at the end of 2016.

Table 2. Study sample in terms of sector, number of companies, employees and market value.

\begin{tabular}{cccc}
\hline Sector & N. & Average Employees & Average Market Value (Billion \$) \\
\hline Consumer Goods & 12 & $142,026.42$ & 81.51 \\
Consumer Services & 6 & $66,428.33$ & 85.05 \\
Financial Services & 11 & $118,080.55$ & 71.35 \\
Health Care & 6 & $68,408.33$ & 85.75 \\
Industrial & 5 & $146,091.80$ & 82.30 \\
Oil \& Gas & 5 & $70,110.40$ & 120.54 \\
Telecommunications & 5 & $185,106.20$ & 80.08 \\
\hline
\end{tabular}

\section{Data Analysis}

Content analysis was performed to identify whether the 50 biggest European companies are disclosing the key content required by the EUG.

Content analysis is defined as "a research technique for making replicable and valid inferences from texts (or other meaningful matter) to the contexts of their use" [65] (p. 18). It is one of the most utilized research methods in disclosure studies [8,57-59]. According to Setia et al. [8], one of the most commonly employed variants of content analysis is based on the simple analysis of the presence or absence of particular items and on the subsequent development of a disclosure index that allows for quantifying the information gathered through the content analysis.

In the present study, the content analysis was performed manually by reading the reports in their entirety $[8,58]$. To quantify the necessary information, a dichotomous coding system was applied by attributing scores of $0 / 1$ for the absence/presence of information $[8,58,59,66]$. Then, an un-weighted disclosure index was employed to quantify the level of compliance of the reports with the EUG. The rationale for the use of an un-weighted index is related to the aim of investigating whether the content elements required by the Directive are included in the report, not at what level those contents are disclosed [18].

More specifically, the reports were analyzed to identify whether the principal content elements required by the EUG regarding non-financial information are provided.

The key contents required by the EUG are the following [24]:

- Business Model

- $\quad$ Policies and Due Diligence

- Outcome

- $\quad$ Principal Risks and Their Management

- Key Performance Indicators

- Environmental Matters

- Social and Employee Matters

- $\quad$ Respect for Human Rights

- Anti-Corruption and Bribery Matters

- Reporting Frameworks

- $\quad$ Board Diversity Disclosure.

The compliance index (CI) has been structured as follows:

$$
\mathrm{CI}=\frac{\sum_{i=1}^{m} d}{m}
$$


where $\sum_{i=1}^{m} d$ is the sum of the content found in the analyzed reports according to the EUG, and $m$ is the maximum number of content obtainable (11).

To assure the accuracy and reliability of the content analysis, the reports were analyzed separately by two researchers, the results were compared and discussed, and the final scores were assigned.

\section{Results and Discussion}

The following sections first present the results obtained by comparing the three documents (the EUG, IFR, and GRI 4 guidelines) and then present the results of the compliance analyses on the reports published by the companies included in the sample.

\subsection{Comparing the Frameworks}

This section outlines the similarities as well as the differences related to the key principles and the content elements required by the EUG, IIRF and GRI 4 guidelines.

As already underlined, the EU Directive requires large undertakings to disclose non-financial information or in the management commentary, as explained in article 4 of the EUG, or to include the required information "in a separate report", as written in the EUG [24] (p. 2). The GRI suggests to prepare a Sustainability Report, by following principles provided in its standards. Essentially, both the EUG and the GRI consider the disclosure of non-financial information separately from financial information. A different viewpoint is given by the IIRF, which requires companies to issue a combined report about "how an organization's strategy, governance, performance and prospects, in the context of its external environment, lead to the creation of value over the short, medium and long-term" [22] (p. 8). Following the approach suggested by the IIRC, a combination of financial and non-financial information of a company's performance should be provided [67] by preparing a report that "comprises both financial and non-financial information" [68] (p. 299).

Although all the frameworks focus on non-financial information, they differ in terms of the audience they address. The EUG and GRI are stakeholder-oriented, while the IIRF focuses on providers of financial capital [53].

More specifically, the aim of the EUG is "to help companies disclose high quality, relevant, useful, consistent and more comparable non-financial (environmental, social and governance-related) information in a way that fosters resilient and sustainable growth and employment, and provides transparency to stakeholders" [24] (p. 4). In the same vein, the purpose of the GRI 4 guidelines is to "offer Reporting Principles, Standard Disclosures and an Implementation Manual for the preparation of sustainability reports by organizations, regardless of their size, sector or location. The GRI guidelines also offer an international reference for all those interested in the disclosure of governance approach and of the environmental, social and economic performance and impacts of organizations" [40] (p. 5). Differently, the IIRF focuses on investors and aims to improve the "quality of information available to providers of financial capital to enable a more efficient and productive allocation of capital" [22] (p. 3). This orientation of the IIRF on capital providers has been identified as a limitation by several scholars [51-53,69]. In particular, regarding the IR framework, Milne and Gray [53] (p. 20) underline that "[d]espite its claims for sustainable development and sustainability, it is exclusively investor focused and it has virtually nothing - and certainly nothing substantive- to say about either accountability or sustainability". Flower [51] argues that although several stakeholders have been engaged in the development of the IIRF, social and environmental stakeholders have not been adequately represented.

The most "demanding" [47] framework seems to be the one proposed by the GRI because it contains a long list of requirements that must be fulfilled by the preparers. The other two frameworks are not setting detailed requirements about the information given, such as strict lists about the content to be inserted in the report. "The Commission encourages companies to avail themselves of the flexibility under the Directive when disclosing nonfinancial information ... " [24] (p. 3). Discussing the approach 
followed by IIRF, scholars already recognize that it "sets out definitions for key concepts and principles that are intended to underpin the content and presentation of integrated reports, and guidelines for the structure and presentation of the reports" [7], and "it is designed to provide guidance for organizations that prepare integrated reports and enable consistency in reporting approaches and content" [70].

Taking stock of the aforementioned similarities and differences, this section compares the key principles and contents of the EUG with those of the IIRF and GRI.

In general, a prevailing convergence between the key principles and content elements required by the three frameworks emerges. However, there are some differences which deserve attention.

Table 3 summarizes the comparison of the frameworks in terms of key principles.

Table 3. Key principles of non-financial disclosure.

\begin{tabular}{ccc}
\hline \multicolumn{3}{c}{ Key Principles } \\
\hline European Guidelines & IIRF & GRI 4 Guidelines \\
\hline Disclose Material Information & $\checkmark$ & $\neq$ \\
Fair, Balanced and Understandable & $\checkmark$ & $\checkmark$ \\
Comprehensive but Concise & $\checkmark$ & $\neq$ \\
Strategic and Forward-Looking & $\checkmark$ & $\checkmark$ \\
Stakeholder Orientated & $\checkmark$ & $\checkmark$ \\
Consistent and Coherent & $\checkmark$ & $\checkmark$
\end{tabular}

Whether the key principles are converging with the other frameworks the symbol $(\checkmark)$ has been inserted; whether the frameworks have different approaches, viewpoints or offer different processes to overcome similar requirement the symbol $(\neq)$ has been introduced.

The similarities between the frameworks are related to the following key principles: Fair, Balanced and Understandable; Strategic and Forward-Looking; Stakeholder Orientated; and Consistent and Coherent. Conversely, there are differences that occur in relation to Disclose Material Information and Comprehensive but Concise.

Moreover, a principle that deserves specific attention is materiality. According to the GRI 4 guidelines [40] (p. 17), materiality includes those aspects that reflect the organization's significant economic, environmental and social impacts or substantively influence the assessments and decisions of stakeholders. These requirements presuppose the concept of materiality as a threshold for the disclosure of information based on a "wide range of impacts and stakeholders" [63] (p. 4). The IIRF has instead led to a change in the process of determining the materiality of information by focusing on "fewer and more strategic issues" [71] (p. 1083) with respect to the GRI 4 guidelines and proposing a four-step process of identification of those relevant matters that have, or may have, an effect on the organization's ability to create value by considering their effects on the organization's strategy, governance, performance or prospects [22] (p. 18). Consequently, the process of implementation of the materiality principle in the IIRF perspective is strictly connected with the specificity of the firm as well as of the industry in which it operates by overcoming the "one size fits all" approach of GRI [71] (p. 1083). The concept of materiality reported in the EUG seems to be much more similar to that expressed in the IIRF, as it refers to the relevance of the impact (positive or adverse) on the company's activity and it requires consideration of the specific company's context and circumstances.

Also, there were relevant differences between the frameworks in terms of the Comprehensive but Concise principle. The GRI 4 guidelines have a different point of view than the EUG, as the GRI 4 guidelines give preparers the possibility to choose "two options for an organization to prepare its sustainability report in accordance with their requirements. The two options are Core and Comprehensive" [40] (p. 7), while the EUG and IIRF require companies to issue a concise, understandable report [22,24].

Table 4 shows the comparison of the EUG with the IIRF and GRI 4 guidelines in terms of content elements. 
Table 4. Content elements of non-financial disclosure.

\begin{tabular}{ccc}
\hline \multicolumn{3}{c}{ Content Elements } \\
\hline European Guidelines & IIRF & GRI 4 Guidelines \\
\hline Business Model & $\checkmark$ & $\neq$ \\
Policies and Due Diligence & $\neq$ & $\checkmark$ \\
Outcomes & $\checkmark$ & $\checkmark$ \\
Principal Risks and Their Management & $\checkmark$ & $\neq$ \\
Key Performance Indicators & $\checkmark$ & $\checkmark$ \\
Environmental Matters & $\checkmark$ & $\checkmark$ \\
Social and Employee Matters & $\checkmark$ & $\neq$ \\
Respect for Human Rights & $\checkmark$ & $\checkmark$ \\
Anti-Corruption and Bribery Matters & $\mathbf{x}$ & $\checkmark$ \\
Board Diversity Disclosure & $\checkmark$ &
\end{tabular}

Whether the content are converging with the other frameworks the symbol $(\mathcal{V})$ has been inserted; whether the frameworks have different approaches, viewpoints or offer different processes to overcome similar requirement the symbol $(\neq)$ has been introduced. The symbol $(\boldsymbol{x})$ has been used in case content are missed.

The business model has been defined as the "DNA of business" [72] (p. 15) because of its crucial importance when improving sustainability [73]. However, the GRI 4 guidelines do not accord the same importance to a company's business model as the other two frameworks do. In fact, while the EUG and the IIRF require disclosing information about how the company is creating value over time, the GRI 4 guidelines require preparers to provide a long list of information about the "Organization Profile" [40].

In addition to the consideration of a company's business model, the frameworks differed in terms of Policies and Due Diligence. While EUG and GRI 4 guidelines require companies to provide this information in a specific section, the IIRF asks companies to consolidate non-financial policies and their outcomes in the same content element (Performance). This approach can be traced back to the principle of Connectivity of Information, which strongly informs the IIRF while requiring entities to "show a holistic picture of the combination, interrelatedness and dependencies between the factors that affect the organization's ability to create value over time" [22] (p. 6).

The connectivity principle has already been discussed by Paternostro [62] who identifies three approaches useful for the combination of the information from partial reports. He recognizes that the concept of connectivity of information is well-developed when explaining the value creation process while is not enough considered when exposing the notion of performance, to this extent the author outlines an important role in the use of the Web for increasing the level of connectivity through the creation of customized IR. Paternostro [62] concludes that the best process for connecting information is "integration in a narrow sense", rather than simply adding all information generally disclosed in separate reports in one document. In doing so, only relevant information should be selected and included in the integrated report to comply with the conciseness principle.

Moreover, differences between the EUG and the GRI 4 guidelines can be identified in the content elements of Key Performance Indicators and Respect for Human Rights. The two divergences toward those two concepts are similar because the GRI 4 Guidelines offer a long list of KPIs (Key Performance Indicators) that can be adopted and detailed information regarding human rights policies. Such an approach reduces flexibility by preparers in comparison with what has been suggested by the EUG and IIRF, enforcing the concept of a "demanding framework", as stated by Skouloudis [47]. Consistently, insights from the practice recognizing that the GRI 4 has too many indicators [74].

Furthermore, while the EUG and GRI 4 guidelines require information regarding Corruption and Anti-Bribery Matters, the IIRF does not. However, the IIRC will take such information into consideration to adjust the IIRF. Information regarding corruption is required not just by the EUG and GRI 4, but also by other frameworks such as the United Nations Global Compact and The Economics of Ecosystems \& Biodiversity [75]. This content element is considered pivotal in Europe because corruption, according to the President of the World Bank, Robert B. Zoellick, is a "cancer that steals from the poor, eats away 
at governance and moral fiber, and destroys trust" [76]. An environment free of corruption can reduce barriers of foreign investments, promote economic growth and encourage the development in evolving countries [77].

Although some scholars consider the EU Directive and the IIRF as "competing frameworks" [61], others view the IIRF as an evolution of the GRI 4 [60]. The present study identifies several close similarities and few differences between the requirements of the three frameworks.

Previous studies, in line with our findings, consider the IIRF "to be the best way to communicate the overall performance of the company to stakeholder" [78] (p. 287).

As already mentioned, European entities are free to adopt the IIRF or GRI 4 guidelines to provide non-financial information. However, to meet the requirements of the EU Directive, entities which will decide to adopt the IIRF should provide information about adopted policies and related outcomes in a separate manner and add data on anti-corruption policies, while entities that will choose to adopt the GRI 4 guidelines should provide additional information on the Business Model.

\subsection{Compliance Analysis}

The second research objective is to analyze 50 of the biggest European companies' readiness for change in terms of non-financial information disclosure. The sample of companies was selected based on market capitalization.

To achieve the research objective, a compliance analysis of annual reports (40) and IR (10) with the EUG was conducted, considering the 11 contents requested by the Directive.

Table 5 introduces the compliance analysis by offering a brief overview of the analyzed reports, specifically in terms of the documents' length.

Table 5. Length of report, on average, per sector.

\begin{tabular}{cccc}
\hline & \multicolumn{3}{c}{ Reporting Length } \\
\hline Sector & Mean & Min & Max \\
Financial Services & 270.6 & 39 & 472 \\
Oil and Gas & 252.2 & 95 & 388 \\
Telecommunication & 247.6 & 188 & 362 \\
Consumer Services & 241.5 & 100 & 457 \\
Industrial & 239.6 & 138 & 344 \\
Consumer Good & 230.5 & 60 & 422 \\
Health Care & 217.5 & 54 & 339 \\
\hline Total Average & 242.79 & 96.29 & 397.71 \\
\hline
\end{tabular}

The reporting length ranges from a minimum of 39 pages to a maximum of 457 pages. The average number of reporting pages is 243.5 . The industrial sector with the highest average number of reporting pages is Financial Services with a mean of 270.6 pages per reports, followed by Oil and Gas (252.2) and Telecommunication (247.6). On the other hand, the Health Care sector shows the lowest average number of pages in a report with a mean of 217.5. As already noted, 204 pages should be enough to contain all the necessary information that an investor needs [79].

Moreover, the analysis shows that $16 \%$ of the analyzed companies disclose their materiality matrix inside their report by adding value to the non-financial disclosure.

Table 6 shows the level of compliance with the EUG of the reports drafted by the 50 companies included in the sample. On average, each firm discloses 7.86 out of 11 content elements. Moreover, the analysis demonstrates a fair level of compliance with the EUG, as the average value of the Compliance Index is 0.71 . Only one company had the minimum score of 0.18 ( 2 content disclosed), while four companies had the maximum score of 1 (all the content elements were disclosed according to the Directive). 
Table 6. The general compliance levels.

\begin{tabular}{ccccc}
\hline & Minimum & Maximum & Mean & Standard Dev \\
\hline N. Content & 2 & 11 & 7.86 & 1.97 \\
Compliance Index & 0.18 & 1 & 0.71 & 0.18 \\
\hline
\end{tabular}

These values are higher than those obtained by Venturelli et al. [58] in their similar compliance research, which was conducted on a sample of 223 Italian large companies as well as by Dyduch and Krasodomska [54] in their research, which was carried out in the Polish context.

Table 7 shows the results of the compliance analysis for each content element required by the EUG. The most disclosed is Social and Employee Matters, with a score of 0.98 (49 companies out of 50 report this item on their reports), followed by Environmental Matters, with a score of 0.94 .

Table 7. The compliance level for content.

\begin{tabular}{clc}
\hline Content & N. & Compliance Index \\
\hline Business Model & 31 & 0.62 \\
Oolicies and Due Diligence & 27 & 0.54 \\
Outcome & 15 & 0.30 \\
Principal Risks and Their Management & 45 & 0.90 \\
Key Performance Indicators & 39 & 0.78 \\
Environmental Matters & 47 & 0.94 \\
Social and Employee Matters & 49 & 0.98 \\
Respect for Human Rights & 34 & 0.68 \\
Anti-Corruption and Bribery Matters & 37 & 0.74 \\
Reporting Frameworks & 20 & 0.40 \\
Board Diversity Disclosure & 41 & 0.82 \\
\hline
\end{tabular}

$\mathrm{N}=$ Number of firms disclosing the content.

These values are higher than those obtained in previous similar studies [54,59]. Unlike the studies conducted by Dyduch and Krasodomska [54] and Guse et al. [59], which focus on a single country, the present research examines a sample composed of the biggest European companies from 10 different countries. Most of the sampled companies are based in countries where mandatory regulations for non-financial disclosure have been required well before the EU Directive was issued (e.g., France, Denmark, Spain, Sweden, UK) [58].

Moreover, all of the sampled companies can be considered entities of public interest. Therefore, it was reasonable to expect a high level of compliance with the EUG, especially in relation to Social and Employee Matters. Indeed, being all large firms, the companies included in the sample are subject to great external social and political pressures concerning the environmental effects of their activities and the implications for social communities [31]. According to the legitimacy theory, a good level of social and environmental disclosure can lead to gains and consolidate the legitimacy within society by demonstrating great compliance with social values, norms, and expectations [16,31]. Disclosure represents a concrete attempt to improve the reputation and the image of the firms within the environment in which they are rooted by mitigating the external pressures exerted by several groups of stakeholders [29].

Furthermore, one the most disclosed content elements is Principal Risks and Their Management, with a score of 0.90 (45 companies out of 50 report this item). Also, this value is higher than the values obtained in previous research $[58,59]$ and can be read in light of the dissatisfaction shown by investors and stakeholders in recent years regarding several corporate scandals and failures, such as those of Enron, Worldcom, and Adelphia, with respect to the general level of risk and risk management disclosure provided by the companies $[44,79,80]$. Indeed, for investors and stakeholders, a higher 
level of risk disclosure allows for conducting a better assessment of the risk profile of a company by reducing the equity cost and improving the market efficiency $[44,46,81]$.

Further, there was a good level of compliance in terms of Board Diversity Disclosure (score of 0.82; 41 companies report this content), Key Performance Indicators (score of $0.78 ; 39$ companies include this item in their reports) and Anti-Corruption and Bribery Matters (score of 0.74; 37 companies report this item), while there was a minimum level of compliance in terms of content related to Outcome, with a score of 0.30 (only 15 companies out of a total of 50 discuss this item in their reports).

Finally, Table 8 shows the results of the compliance analysis for each of the content elements required by the EUG in terms of the sectors in which the sampled companies were grouped.

Unlike in the previous study of Matuszak and Rózanska [57] and consistent with the study of Guse et al. [59], this study presents low variation among the sectors in terms of level of compliance.

This result indicates that there is a common awareness among firms that they must provide an exhaustive amount of social and environmental disclosure through their non-financial reports in order to maintain legitimacy within the different environments in which the firms are rooted. The compliance with the EUG and specifically with the Social and Employee Matters and Environmental Matters among the different industries is a clear signal of a widespread behavior to obtain legitimacy based on respect for the social contract signed with the stakeholders.

However, unlike in previous studies [59], in this study the Industrial sector displayed the maximum Compliance Index score of 0.78 , and the Health Care sector demonstrated a score of 0.77. Furthermore, the minimum Compliance Index score was obtained by the Consumer Services sector, with a score of 0.64. An explanation for this result derives from the nature of the Industrial sector, which can be considered environmentally sensitive and socially exposed, as the sector is composed of firms carrying out activities that have deep impacts on the external environment. Consistent with legitimacy theory, firms belonging to environmentally sensitive industries tend to provide massive social and environmental disclosure regarding the effects of their activities in order to reduce external pressures and protect themselves from possible threats to their legitimacy $[29,31,37,38,42,43]$. In doing so, these firms increase their transparency and accountability toward the social community in which they are rooted by reducing concerns about the potential negative effects of their business [31]. 
Table 8. The compliance level for industry sectors.

\begin{tabular}{|c|c|c|c|c|c|c|c|c|c|c|c|c|c|}
\hline Industry & N. & $\begin{array}{c}\text { Business } \\
\text { Model }\end{array}$ & $\begin{array}{l}\text { Policies and } \\
\text { Due } \\
\text { Diligence }\end{array}$ & Outcome & $\begin{array}{c}\text { Principal Risk } \\
\text { and their } \\
\text { Management }\end{array}$ & KPIs & $\begin{array}{c}\text { Environmental } \\
\text { Matters }\end{array}$ & $\begin{array}{c}\text { Social and } \\
\text { Employee } \\
\text { Matters }\end{array}$ & $\begin{array}{c}\text { Respect for } \\
\text { Human } \\
\text { Rights }\end{array}$ & $\begin{array}{l}\text { Anti-Corruption } \\
\text { and Bribery }\end{array}$ & $\begin{array}{c}\text { Reporting } \\
\text { Framework }\end{array}$ & $\begin{array}{c}\text { Board } \\
\text { Diversity } \\
\text { Disclosure }\end{array}$ & $\begin{array}{c}\text { Total } \\
\text { Compliance } \\
\text { Index Score }\end{array}$ \\
\hline Consumer Goods & 12 & 0.67 & 0.58 & 0.33 & 0.92 & 0.90 & 0.92 & 1.00 & 0.83 & 0.58 & 0.25 & 0.83 & 0.70 \\
\hline Consumer Services & 6 & 0.67 & 0.33 & 0.00 & 0.83 & 0.67 & 1.00 & 1.00 & 0.50 & 0.83 & 0.33 & 0.83 & 0.64 \\
\hline Financial Services & 11 & 0.55 & 0.73 & 0.40 & 1.00 & 0.73 & 1.00 & 1.00 & 0.70 & 0.91 & 0.18 & 0.82 & 0.72 \\
\hline Health Care & 6 & 1.00 & 0.50 & 0.33 & 0.83 & 1.00 & 1.00 & 1.00 & 0.83 & 0.83 & 0.50 & 0.67 & 0.77 \\
\hline Industrial & 5 & 0.80 & 0.60 & 0.40 & 1.00 & 0.80 & 1.00 & 1.00 & 0.60 & 0.80 & 0.60 & 1.00 & 0.78 \\
\hline Oil \& Gas & 5 & 0.60 & 0.40 & 0.40 & 1.00 & 0.80 & 1.00 & 1.00 & 0.60 & 0.80 & 0.60 & 0.80 & 0.73 \\
\hline Telecommunications & 5 & 1.00 & 0.40 & 0.00 & 1.00 & 0.80 & 0.60 & 0.80 & 0.60 & 0.80 & 0.60 & 1.00 & 0.69 \\
\hline Total & 50 & 0.72 & 0.54 & 0.29 & 0.94 & 0.81 & 0.94 & 0.98 & 0.69 & 0.78 & 0.38 & 0.84 & 0.71 \\
\hline
\end{tabular}

(Source: Authors' compilation). 
Table 9 concludes the analysis. It shows that 15 firms out of the 50 sampled firms receive external assurance for the non-financial information they disclose. Among these, 11 of the firms selected a Big 4 accounting firm as an external assurance provider. This result offers interesting insights in terms of legitimacy theory. Specifically, external assurance represents an effective instrument for improving the credibility and perceived quality of non-financial information provided in the reports. Consequently, the choice to select an external provider to assure the non-financial information disclosed in annual reports signals to stakeholders the firm's commitment to sustainability by ensuring more legitimacy $[3,6]$.

Table 9. External Assurance.

\begin{tabular}{ccc}
\hline \multicolumn{3}{c}{ External Assurance } \\
\cline { 1 - 2 } Yes & No \\
\cline { 1 - 2 } Big 4 & Not Big 4 & \\
\hline 11 & 4 & 35 \\
\hline
\end{tabular}

\section{Conclusions}

The growing attention on environmental and social sustainability, as well as to CSR, led the European Union to issue a specific Directive in 2014 [23] and related guidelines [24] to mandate European entities of public interest to provide adequate information that meets stakeholders' information needs. The final aim of the Directive is to the expand the process of harmonization from the disclosure of financial data-already provided in accordance with the IFRS by listed companies in all European Countries-to the disclosure of non-financial information. However, non-financial disclosure has been traditionally voluntary in nature. Thus, the European Union has allowed companies to choose the framework they wish to adopt to provide the information required by the Directive. Considering the European context and adopting a legitimacy theory perspective, the present study demonstrates de jure and de facto evidence to understand the readiness for change of European companies of public interest. First, an analysis of the coherence between the EUG and the two main frameworks related to non-financial disclosure, the GRI 4 guidelines and the IIRF, was conducted. Moreover, to assess the readiness for change of the 50 biggest European companies selected on the basis of market capitalization, a compliance analysis, which compared annual reports published by the sampled companies with the EUG, was conducted.

The results of the study offer interesting insights. First, the comparison of the EUG with IIRF and GRI 4 guidelines highlights that some content elements required by the Directive are not included in the requirements of the other two frameworks. Thus, companies wishing to adopt the IIRF or the GRI 4 must bear in mind that some specific information must be included in their reports to comply with the requirements of the Directive. More specifically, in case the company adopts the GRI 4, managers need to be aware about the need to include information on the business model and on the Respect of Human Rights. Conversely, whenever the company has adopted the IIRF, information on Policies and Due Diligence and on anti-corruption and bribery matters need to be added.

The content analysis of the reports collected by the 50 sampled companies reveals that there is already a high level of compliance by big European companies with the EUG. This behavior testifies how big undertakings look for legitimacy in a market-as Europe is-aware of environmental and sustainability issue. Some of the slight differences that were found among companies that belong to different sectors can be explained by the greater attention to disclosure paid by those entities operating in environmentally sensitive industries. Consistent with a legitimacy approach, firms belonging to environmentally sensitive industries tend to provide more comprehensive social and environmental disclosure regarding the impact produced by their business to reduce the potential concern by the communities in which they are rooted and to gain respect on the market and thus legitimize their 
actions. Moreover, the analysis found that companies are increasingly using integrated reports to consolidate financial and non-financial information and disclose them in a more concise manner.

Managers in the future may consider the possibility to prepare integrated reports, adding those information required by the EUG. Meanwhile standard setters-in particular the IIRC-may consider to include in their framework the non-financial information required by the EUG.

Furthermore, the high level of compliance emerged by analyzing the first 50 companies in Europe may suggest to the European legislator to mandate the adoption of the EUG to all listed companies in the European market.

To expand on the results of the current analysis, future studies can include other companies and other countries in their samples to further investigate the determinants of non-financial disclosure. In fact, one of the limitations of the current study is the limited number of companies included in the sample. Moreover, an analysis that covers more years may shed light on the evolution of non-financial disclosure in Europe.

Author Contributions: All authors wrote the paper, but their primary individual contributions were as follows: Section 1 is to be ascribed to Francesca Manes-Rossi, Sections 2 and 3 are to be ascribed to Giuseppe Nicolò, Section 4 is to be ascribed to Gianluca Zanellato, and Section 5 is to be ascribed to Adriana Tiron-Tudor.

Conflicts of Interest: The authors declare no conflict of interest.

\section{References}

1. Guthrie, J.; Farneti, F. GRI sustainability reporting by Australian public_Sector Organizations. Public Money Manag. 2008, 28, 361-366. [CrossRef]

2. Kolk, A. Sustainability, accountability and corporate governance: Exploring multinationals' reporting practices. Bus. Strategy Environ. 2008, 17, 1-15. [CrossRef]

3. Simnett, R.; Vanstraelen, A.; Chua, W.F. Assurance on sustainability reports: An international comparison. Account. Rev. 2009, 84, 937-967. [CrossRef]

4. Stojanović-Blab, M.; Blab, D.; Spasić, D. Sustainability reporting-a challenge for Serbian companies. TEME 2016, 4, 1349-1366.

5. De Villiers, C.; Hsiao, P.-C.K.; Maroun, W. Developing a conceptual model of influences around integrated reporting, new insights and directions for future research. Meditari Account. Res. 2017, 25, 450-460. [CrossRef]

6. Ioannou, I.; Serafeim, G. The Consequences of Mandatory Corporate Sustainability Reporting; Harvard Business School: Boston, MA, USA, 2017; pp. 1-100.

7. Wild, S.; van Staden, C. Integrated reporting: Initial analysis of early reporters-An institutional theory approach. In Proceedings of the 7th Asia Pacific Interdisciplinary Accounting Research Conference, Kobe, Japan, 26-28 July 2013; pp. 1-38.

8. Setia, N.; Abhayawansa, S.; Joshi, M.; Vu Huynh, A. Integrated reporting in South Africa: Some initial evidence. Sustain. Account. Manag. Policy J. 2015, 6, 397-424. [CrossRef]

9. Dumay, J.; Dai, T. Integrated thinking as a cultural control? Meditari Account. Res. 2017, 25, 574-604. [CrossRef]

10. De Villiers, C.; Rinaldi, L.; Unerman, J. Integrated Reporting: Insights, gaps and an agenda for future research. Account. Audit. Account. J. 2014, 27, 1042-1067. [CrossRef]

11. Raemaekers, K.; Maroun, W.; Padia, N. Risk disclosures by South African listed companies post-King III. S. Afr. J. Account. Res. 2016, 30, 41-60. [CrossRef]

12. Truant, E.; Corazza, L.; Scagnelli, S.D. Sustainability and risk disclosure: An exploratory study on sustainability reports. Sustainability 2017, 9, 636. [CrossRef]

13. Marx, B.; Mohammadali-Haji, A. Emerging trends in reporting: An analysis of integrated reporting practices by South African top 40 listed companies. J. Econ. Financ. Sci. 2014, 7, 231-250.

14. Milne, M.J.; Gray, R. Future prospects for corporate sustainability reporting. Sustain. Account. Account. 2007, 1, 184-207.

15. Bebbington, J.; Unerman, J.; O’Dwyer, B. Sustainability Accounting and Accountability; Routledge: New York, NY, USA, 2014. 
16. Guthrie, J.; Parker, L.D. Corporate social reporting: A rebuttal of legitimacy theory. Account. Bus. Res. 1989, 19, 343-352. [CrossRef]

17. Gray, R.; Owen, D.; Maunders, K. Corporate Social Reporting: Accounting and Accountability; Prentice-Hall International: Upper Saddle River, NJ, USA, 1987.

18. Guthrie, J.; Parker, L.D. Corporate social disclosure practice: A comparative international analysis. Adv. Public Interest Account. 1990, 3, 159-175.

19. Solomon, J.; Maroun, W. Integrated Reporting: The Influence of King III on Social, Ethical and Environmental Reporting; The Association of Chartered Certified Accountants: London, UK, 2012.

20. Eccles, R.G.; Krusz, M. One Report: Integrated Reporting for a Sustainable Strategy; John Wiley \& Sons, Inc.: Hoboken, NJ, USA, 2010.

21. Churet, C.; Eccles, R.G. Integrated reporting, quality of management, and financial performance. J. Appl. Corp. Financ. 2014, 26, 56-64.

22. Integrated Reporting. International Integrated Reporting Framework. 2013. Available online: www. integratedreporting.org/resource/international-ir-framework/ (accessed on 23 January 2018).

23. EU Commission. Directive 2014/95/EU of the European Parliament and the Council of 22 October 2014 amending Directive 2013/34/EU as Regards Disclosure of Non-Financial and Diversity Information by Certain large Undertakings and Groups; EU Commission: Brussels, Belgium, 2014; pp. 1-9.

24. European Commission. Guidelines on Non-Financial Reporting (Methodology for Reporting Non-Financial Information) (2017/C 215/01); European Commission: Brussels, Belgium, 2017; Available online: www.ec.europa.eu/antitrafficking/sites/antitrafficking/files/guidelines_on_non-financial_reporting.pdf (accessed on 23 January 2018).

25. Idowu, S.O.; Dragu, I.M.; Tiron-Tudor, A.; Farcas, T.V. From CSR and sustainability to integrated reporting. Int. J. Soc. Entrepreneurship Innov. 2016, 4, 134-151. [CrossRef]

26. Hackston, D.; Milne, M.J. Some determinants of social and environmental disclosures in New Zealand companies. Account. Audit. Account. J. 1996, 9, 77-108. [CrossRef]

27. Prado-Lorenzo, J.M.; Rodríguez-Domínguez, L.; Gallego-Álvarez, I.; García-Sánchez, I.M. Factors influencing the disclosure of greenhouse gas emissions in companies world-wide. Manag. Decis. 2009, 47, 1133-1157. [CrossRef]

28. Nolan, J. Corporate Accountability and Triple Bottom Line Reporting: Determining the Material Issues for Disclosure. In Enhancing Corporate Accountability: Prospects and Challenges Conference Proceedings; University of New South Wales: Kensington, Australia, 2007.

29. Patten, D.M.; Zhao, N. Standalone CSR reporting by U.S. retail companies. Account. Forum 2014, 38, $132-144$. [CrossRef]

30. Gray, R.; Kouhy, R.; Lavers, S. Corporate social and environmental reporting: A review of the literature and a longitudinal study of UK disclosure. Account. Audit. Account. J. 1995, 8, 47-77. [CrossRef]

31. Deegan, C.; Gordon, B. A study of the environmental disclosure practices of Australian corporations. Account. Bus. Res. 1996, 26, 187-199. [CrossRef]

32. Deegan, C.; Rankin, M. Do Australian companies report environmental news objectively? An analysis of environmental disclosures by firms prosecuted successfully by the Environmental Protection Authority. Account. Audit. Account. J. 1996, 9, 50-67. [CrossRef]

33. Patten, D.M. Intra-industry environmental disclosures in response to the Alaskan oil spill: A note on legitimacy theory. Account. Organ. Soc. 1992, 17, 471-475. [CrossRef]

34. Roberts, R.W. Determinants of corporate social responsibility disclosure: An application of stakeholder theory. Account. Organ. Soc. 1992, 17, 595-612. [CrossRef]

35. Lindblom, C.K. The Implications of Organizational Legitimacy for Corporate Social Performance and Disclosure; Conference Paper, Critical Perspectives on Accounting Conference, New York; Scientific Research Publishing: Wuhan, China, 1994.

36. Deegan, C.; Rankin, M.; Tobin, J. An examination of the corporate social and environmental disclosures of BHP from 1983-1997: A test of legitimacy theory. Account. Audit. Account. J. 2002, 15, 312-343. [CrossRef]

37. Cho, C.H.; Michelon, G.; Patten, D.M.; Roberts, R.W. CSR disclosure: The more things change ... ? Account. Audit. Account. J. 2015, 28, 14-35. [CrossRef]

38. Cho, C.H.; Patten, D.M. The role of environmental disclosures as tools of legitimacy: A research note. Account. Organ. Soc. 2007, 32, 639-647. [CrossRef] 
39. Patten, M.D.; Ren, Y.; Zhao, N. Standalone corporate social responsibility reporting in China: An exploratory analysis of its relation to legitimation. Soc. Environ. Account. J. 2015, 35, 17-31. [CrossRef]

40. Global Reporting Initiative. G4 Guidelines-Reporting Principles and Standard Disclosures. 2013. Available online: www.globalreporting.org (accessed on 20 January 2018).

41. Cho, C.H.; Michelon, G.; Patten, D.M. Enhancement and obfuscation through the use of graphs in sustainability reports: An international comparison. Sustain. Account. Manag. Policy J. 2012, 3, 4-88. [CrossRef]

42. Guthrie, J.; Cuganesan, S.; Ward, L. Industry specific social and environmental reporting: The Australian food and beverage Industry. Account. Forum 2008, 32, 1-15. [CrossRef]

43. Guthrie, J.; Cuganesan, S.; Ward, L. Disclosure media for social and environmental matters within the Australian food and beverage industry. Soc. Environ. Account. J. 2008, 28, 33-44. [CrossRef]

44. Abraham, S.; Cox, P. Analysing the determinants of narrative risk information in UK FTSE 100 annual reports. Br. Account. Rev. 2007, 39, 227-248. [CrossRef]

45. Abraham, S.; Shrives, P.J. Improving the relevance of risk factor disclosure in corporate annual reports. Br. Account. Rev. 2014, 46, 91-107. [CrossRef]

46. Moolman, J.; Oberholzer, M.; Steyn, M. The effect of integrated reporting on integrated thinking between risk, opportunity and strategy and the disclosure of risks and opportunities. S. Afr. Bus. Rev. 2016, 20, 600-627.

47. Skouloudis, A.; Evangelinos, K.; Kourmousis, F. Development of an evaluation methodology for triple bottom line reports using international standards on reporting. Environ. Manag. 2009, 44, 298-311. [CrossRef] [PubMed]

48. Guthrie, J.; Petty, R.; Ricceri, F. The voluntary reporting of intellectual capital: Comparing evidence from Hong Kong and Australia. J. Intellect. Cap. 2006, 7, 254-271. [CrossRef]

49. Deegan, C. Introduction: The legitimising effect of social and environmental disclosures-A theoretical foundation. Account. Audit. Account. J. 2002, 15, 282-311. [CrossRef]

50. García-Sánchez, I.M.; Rodríguez-Ariza, L.; Frías-Aceituno, J.V. The cultural system and integrated reporting. Int. Bus. Rev. 2013, 22, 828-838. [CrossRef]

51. Flower, J. The international integrated reporting council: A story of failure. Crit. Perspect. Account. 2015, 27, 1-17. [CrossRef]

52. Dumay, J.; Bernardi, C.; Guthrie, J.; La Torre, M. Barriers to implementing the International Integrated Reporting Framework: A contemporary academic perspective. Meditari Account. Res. 2017, 25, 461-480. [CrossRef]

53. Milne, M.J.; Gray, R. W(h)ither ecology? The triple bottom line, the global reporting initiative, and corporate sustainability reporting. J. Bus. Ethics 2013, 118, 13-29. [CrossRef]

54. Dyduch, J.; Krasodomska, J. Determinants of corporate social responsibility disclosure: An empirical study of Polish listed companies. Sustainability 2017, 9, 1934. [CrossRef]

55. Michelon, G.; Pilonato, S.; Ricceri, F. CSR reporting practices and the quality of disclosure: An empirical analysis. Crit. Perspect. Account. 2015, 33, 59-78. [CrossRef]

56. Kristofik, P.; Lament, M.; Musa, H. The reporting of non-financial information and the rationale for its standardisation. Econ. Manag. 2016, 19, 157. [CrossRef]

57. Matuszak, Ł.; Różańska, E. CSR disclosure in Polish-listed companies in the light of Directive 2014/95/EU requirements: Empirical evidence. Sustainability 2017, 9, 2304. [CrossRef]

58. Venturelli, A.; Caputo, F.; Cosma, S.; Leopizzi, R.; Pizzi, S. Directive 2014/95/EU: Are Italian companies already compliant? Sustainability 2017, 9, 1385. [CrossRef]

59. Guse, R.G.; Almasan, A.; Circa, C.; Dumitru, M. The role of the stakeholders in the institutionalization of the CSR reporting in Romania. Account. Manag. Inf. Syst. 2016, 15, 304-340.

60. Mio, C.; Fasan, M. The Determinants of Materiality Disclosure in Integrated Corporate Reporting; Ca' Foscari University of Venice: Venice, Italy, 2014.

61. Monciardini, D.; Dumay, J.; Biondi, L. Integrated Reporting and EU Law. Competing, Converging or Complementary Regulatory Frameworks? University of Oslo Faculty of Law Research Paper No. 2017-23; University of Oslo Faculty of Law: Oslo, Norway, 2017; Available online: https:/ / ssrn.com/abstract=2981674 (accessed on 27 December 2017). 
62. Paternostro, S. The connectivity of information for the integrated reporting. In Integrated Reporting. Concepts and Cases that Redefine Corporate Accountability; Busco, C., Frigo, M.L., Riccaboni, A., Quattrone, P., Eds.; Springer: London, UK, 2013; pp. 59-78.

63. Lai, A.; Melloni, G.; Stacchezzini, R. What does materiality mean to integrated reporting preparers? An empirical exploration. Meditari Account. Res. 2017, 25, 533-552. [CrossRef]

64. European Commission. Directive 2006/43/EC of the European Parliament and of the Council of 17 May 2006 on Statutory Audits of Annual Accounts and Consolidated Accounts, Amending Council Directives 78/660/EEC and 83/349/EEC and Repealing Council Directive 84/253/EEC; European Commission: Brussels, Belgium, 2006.

65. Krippendorff, K. Content Analysis: An. Introduction to Its Methodology; Sage Publications, Inc.: Thousand Oaks, CA, USA, 1980.

66. Incollingo, A.; Bianchi, M. The connectivity of information in integrated reporting. Empirical evidence from international context. Financ. Rep. 2016, 2, 55-78. [CrossRef]

67. Eccles, R.G.; Saltzman, D. Achieving sustainability through integrated reporting. Stanf. Soc. Innov. Rev. 2011, 9, 56-61.

68. Jensen, J.C.; Berg, N. Determinants of traditional sustainability reporting versus integrated reporting. An institutionalist approach. Bus. Strategy Environ. 2012, 21, 299-316. [CrossRef]

69. Dumay, J.; Bernardi, C.; Guthrie, J.; Demartini, P. Integrated reporting: A structured literature review. Account. Forum 2016, 40, 166-185. [CrossRef]

70. Lodhia, S.; Stone, G. Integrated reporting in an internet and social media communication environment: Conceptual insights. Aust. Account. Rev. 2017, 27, 17-33. [CrossRef]

71. Stubbs, W.; Higgins, C. Integrated reporting and internal mechanisms of change. Account. Audit. Account. J. 2014, 27, 1068-1089. [CrossRef]

72. Elkington, J. Enter the triple bottom line. In The Triple Bottom Line, Does it All Add Up? Henriques, A., Richardson, J., Eds.; Earthscan Publications: London, UK, 2004; pp. 1-16.

73. Schaltegger, S.; Lüdeke-Freund, F.; Hansen, E.G. Business cases for sustainability: The role of business model innovation for corporate sustainability. Int. J. Innov. Sustain. Dev. 2012, 6, 95-119. [CrossRef]

74. Adams, C.A.; McNicholas, P. Making a difference: Sustainability reporting, accountability and organisational change. Account. Audit. Account. J. 2007, 20, 382-402. [CrossRef]

75. Abeysekera, I. A template for integrated reporting. J. Intellect. Cap. 2013, 14, 227-245. [CrossRef]

76. PwC. PricewaterhouseCoopers: "Confronting Corruption: The Business Case for an Effective Anti-Corruption Programme"; PwC: London, UK, 2008; Available online: www.pwc.com/th/en/publications/assets/ confronting_corruption_printers.pdf (accessed on 29 January 2018).

77. Hess, D.; Dunfee, T. Taking responsibility for bribery: The multinational corporation's role in combating corruption. Bus. Hum. Rights 2003, 260-271. [CrossRef]

78. Sierra-García, L.; Zorio-Grima, A.; García-Benau, M.A. Stakeholder engagement, corporate social responsibility and integrated reporting: An exploratory study. Corp. Soc. Responsib. Environ. Manag. 2015, 22, $286-304$. [CrossRef]

79. Enslin, Z.; Bruwer, W.; Viljoen, C. Enhancing risk-related disclosure in South Africa: A study on guidelines and current practices. J. Econ. Financ. Sci. 2015, 8, 261-280.

80. Saggar, R.; Singh, B. Corporate governance and risk reporting: Indian evidence. Manag. Audit. J. 2017, 32, 378-405. [CrossRef]

81. Haller, A.; van Staden, C. The value-added statement-An appropriate instrument for Integrated Reporting. Account. Audit. Account. J. 2014, 27, 1190-1216. [CrossRef]

(C) 2018 by the authors. Licensee MDPI, Basel, Switzerland. This article is an open access article distributed under the terms and conditions of the Creative Commons Attribution (CC BY) license (http://creativecommons.org/licenses/by/4.0/). 